\title{
Hamlet as a Superfluous Hero
}

\author{
Javed Akhter, Shumaila Abdullah, Khair Muhammad
}

Department of English Literature and Linguistics, University of Balochistan, Quetta, Pakistan

\section{Email Address:}

sangatjavedakhtar@gmail.com (J.Akhter),Shumaila_abdullah914@yahoo.com (A. Shumaila), Khairefroze@gmail.com (K. Muhammad)

\section{To cite this article:}

Javed Akhter, Shumaila Abdullah, Khair Muhammad. Hamlet as a Superfluous Hero. International Journal of Literature and Arts.

Vol. 3, No. 5, 2015, pp. 120-128. doi: 10.11648/j.ijla.20150305.18

\begin{abstract}
The aim of this research paper is to prove William Shakespeare's most popular literary type Hamlet as a superfluous hero, because he resembles strikingly and astonishingly in his character with the superfluous heroes of the nineteenth-century Russian, American and the other European novels. In fact, the term superfluous hero signifies an ineffectual aristocrat, dreamy, useless and incapable intellectual at odd with the given social formation of his age. No doubt, though, Hamlet is prior to the coinage of the term of the superfluous hero, but he shares many common characteristics with the superfluous heroes of world literature. Thus, the study revolves around the question whether Hamlet is the superfluous hero? Therefore, the comparison of Hamlet's character with those of the other superfluous heroes of world literature will be highlighted in this research paper in terms of Marxist hermeneutics, which is scientific theory and method of analysing the social and literary types in the socio-economic context of class milieu. Applying Marxist literary hermeneutics to the art of characterisation of William Shakespeare and the authors of the nineteenth-century, the present study tries to introduce new portrait and re-evaluation of the personages of Hamlet and the other superfluous types in an innovative perspective.
\end{abstract}

Keywords: William Shakespeare's Hamlet, Hamletism, Superfluous Heroes, Indecision, Procrastination

\section{Introduction}

William Shakespeare was pre-eminently a great producer of typical literary characters. He possessed so extensive knowledge of human psychology that he was able to delineate memorable and universal types of flesh and blood in his plays, which were able to transcend the limits of time and space. Therefore, William Shakespeare's contribution to cogitation of human types was profound and astonishing. From the age of William Shakespeare until the present PostModern age, his plays continue to mind for insights into human psychology. However, "The Tragedy of Hamlet, Prince of Denmark" of William Shakespeare's tragedies, has aroused the great amount of debate and critical commentary. William Shakespeare produced a universal literary type in the figure of Hamlet in the Elizabethan era, which has become immortal and universal character in world literature. Hamlet seems close to the social types of every era and country as well as the contemporary world. That is why Hamlet is one of the most discussed of William Shakespeare's debatable characters. He is so complex psychological type who becomes an enigma and so dominant a character in the play, who outshines all the other characters of the play.

Nevertheless, Hamlet shares the inability and superfluousness with the superfluous heroes of world literature to find purpose in his life. Although Hamlet seems distinct from the superfluous heroes of world literature at first glance, but he resembles them at great extent and he is made of the same fabric. In this sense, Hamlet comes from the line of the superfluous heroes of world literature. Like other superfluous heroes of world literature, Hamlet fails to find purpose, meaning and dimension in his life. Nevertheless, Hamlet as a "useless chap" and superfluous hero is not altogether a new type in world literature. The concept of "useless chap" in fact, emerges with Alexander Pushkin's type Eugene Onegin in his verse novel "Eugene Onegin" and culminates its height in Goncharov's Oblomov and called the "useless chap" or the superfluous hero.

In fact, the tradition of the superfluous hero is one of the most important developments in the Golden Age of Russian literature. The Golden Age of Russian literature is the nineteenth-century. The tradition of the superfluous hero emerged with the early novels of Alexander Pushkin, Nikolay Gogol, Alexander Herzen, Mikhail Lermontov, Ivan Goncharov, and Ivan Turgenev in the nineteenth century, climaxing in the great novels of Fyodor Dostoevsky and Leo Tolstoy with a key cultural struggle for self-understanding of a Russian intellectual elite looking for solid ground. In fact, 
the term superfluous hero is used to refer to an ineffectual aristocrat, dreamy, useless and incapable intellectual who does not fit in the given social formation of his age. The roots of this term can be traced back to the mid-nineteenth century, just after the publication of Ivan Turgenev's novel "The Diary of a Superfluous man", in 1850. The term superfluous hero gained prominence with the publication of the novel, which has been applied to a particular type of characters of an earlier period of the nineteenth century as well as that of in the middle years of the century and beyond, into the twentieth century.

Yet it would be hard to imagine a term superfluous hero more loosely and generally applied or more inadequately defined. The concept of the superfluous hero emerges with the publication of Alexander Pushkin's Evgenii Onegin in "Evgenii Onegin", and extends to Ivan Turgenev's characters Chulkaturin, in "The Diary of a Superfluous man", Rudin in "Rudin", Bazarov in "Fathers and Sons", Lupikhin in "Hamlet of the Shchigrovsky District. The thread continues in Mikhail Lermontov's hero Pechorin in "A Hero of Our Time" and Alexander Herzen's Beltov in "Who is to Blame?" The concept culminates the figures of Ivan Goncharov's Oblomov, Fyodor Dostoevsky's Stepan Trofimovich Verkhovensky in "The Devils", and Leo Tolstoy's Andrei Bolkonsky in "War and Peace". These are just a few characters of Russian literature that have made the register of the superfluous heroes simply by not fitting in or evincing a general disillusionment and disenchantment with the social formation, the political system, or the status quo of their time.

Although, the tradition of superfluous hero is specific to Russia, but the term was most commonly used to refer to certain characters of world literature, however, this term superfluous hero is not only confined to Russian literature. This term is also part of a broader phenomenon in world literature. This term may be applied to all such type of characters as Evgenii Onegin, Chulkaturin, Rudin, Bazarov, Oblomov, Stepan Trofimovich Verkhovensky and Andrei Bolkonsky. When we study the British dramatist William Shakespeare's "The Tragedy of Hamlet, the Prince of Denmark"; or Friedrich Schiller's play, "The Robbers" (1871); or Kate Chopin's novel, "The Awakening” (1899); or the French director Eric Rohmer's film, "Chloe in the Afternoon" (1972); we may trace the origin of the superfluous hero tradition in these novels. These novels round up into a shorn herd of superfluous heroes. Moreover, the list of the superfluous heroes may be expanded back to William Shakespeare's character type of Hamlet, Lord Byron's Don Juan, Dickens' Ebenezer Scrooge, Hugo's Enjolras and many other famous literary character types of world literature who are still not recognized as the superfluous heroes in the history of world literature. Therefore, the present research paper tends to prove that the term superfluous hero may also be applied to William Shakespeare's Hamlet who like other superfluous heroes of world literature is tragically doomed to failure in his life and purpose.

\section{Literature Review}

William Shakespeare produced a literary type in the personality of Hamlet, which has become immortal and universal character in world literature. That is why Hamlet is one of the most discussed of William Shakespeare's characters. The Romantics opine Hamlet as "inverted Aristotle's stress on primacy of action over character" (De Grazia, Margreta, 1999, p. 254). To Fredrick Hegel, Hamlet embodied the quest for "self-conscious and selfdetermination" (De Grazia, Margreta, 1999, P. 255). A. C Bradley followed Fredrick Hegel to formulate his "key principle of Shakespearean tragedy: "action is essentially the expression of character" (De Grazia, Margreta, 1999, P. 257). The story of Hamlet concerns a young prince with a ghost of his dead father who talks only to him and instructs him to commit a revenge murder. Hamlet is tragically doomed to failure to avenge from his uncle King Claudius, the slayer of his father because of indecision and procrastination. Therefore, he delayed and deferred his action in the whole play.

However, William Shakespeare's Hamlet has aroused the great amount of debate and critical commentary among the literary critics and literary theorists. No critic from the Elizabethan period until of the present day has been able to neglect this complex and problematic literary character. A critical theory become fashionable and out of fashion in academia and scholarship, but always Hamlet remains the focal and central point of debate and great controversy in literary criticism. Most of the critics agree on the point that Hamlet is an irresolute and indecisive character. The NeoClassicists fixed their gaze on his indecision. The Romantics also concentrate completely on this characteristic of Hamlet. S. T Coleridge says, "Seemingly accomplished for the greatest actions, whose existence is nevertheless an unperforming dream" (S.T Coleridge in Jump, John, 1968, p. 31). William Hazlitt, S.T Coleridge, A. C Bradley and Sigmund Freud opine Hamlet's hesitation as "only an excuse for his want of resolution" (William Hazlitt quoted in Jenkins, Harold, 1982, p. 513).

Sigmund Freud psychoanalysed the character of Hamlet in his works. The classic example of Freudian psychoanalytic approach is, of course, Doctor. Alfred Ernest Jones's study of Hamlet provides a solution to the puzzle of Hamlet's delay in avenging his father in a full-scale psychoanalytic treatment of Hamlet's character in his essay "Hamlet and Oedipus" (1957). Moreover, the psychoanalytical critics trumped selfconsciousness, claiming that only the Freudian Unconscious "can account for why a character distinguished by selfreflection cannot know his own motives" (De Grazia, Margreta, 1999, P. 260). Restudying Sigmund Freud, Jacques Lacan in his essay "Desire and the Interpretation of Desire in Hamlet" (1959), redefined the character of Hamlet-and modern awareness-no longer reading the text as tragedy merely of repressed desire but as a tragedy of "mourning for what it has had to give up" (De Grazia, Margreta, 1999, P. 261). 
In addition, Jacques Derrida also took interest in William Shakespeare's plays especially in "Romeo and Juliet" and "Hamlet, employing his deconstructive hermeneutics, whish yields very interesting and thought provoking results. He identified the Ghost of Hamlet with the Marxian "spectre" haunting Europe in the first line of the Communist Manifesto in his book "Spectres of Marx" (1994). In the deconstructionist reading, Hamlet represents "a certain emancipator and messianic affirmation" (De Grazia, Margreta, 1999, P. 264), implying an absolute justice "beyond the logic of vengeance" existing in a non-linear "deferred time" (De Grazia, Margreta, 1999, P. 265). In this manner, Jacques Derrida's book "Spectres of Marx" inspired the critics to study Hamlet in a Derridean deconstructive manner. Therefore, Sedinger studied various facets of Hamlet's character to extend the discussion of Jacques Derrida's book "Spectres of Marx" (2007) in the context of historical critiques of presentation. Marthinus Christoffel Van Niekerk in his dissertation entitled "Shakespeare's Play: deconstructive reading of the Merchant of Venice, the Tempest, Measure for Measure and Hamlet" (2003) analysed Hamlet in a Derridean deconstructive perspective. Noorbakhsh Hooti also did so in his research paper entitled "William Shakespeare's Hamlet: A Deconstructive Study" (2013).

Furthermore, New Historicist and cultural materialist critics fully concentrated on William Shakespeare's Hamlet. They argue that subjects cannot transcend their own time but live and work within the horizon of a culture constructed by ideology. The major common assumptions between new historicism and cultural materialism are the ideological constructions that authors live in and have internalized, inevitably become part of their work, which is therefore always political and vehicle for power struggle. As Dollimore and Sinfield put that "a play by Shakespeare is related to the context of its production-to economic and political system of Elizabethan and Jacobean England and to particular institutions of cultural production (the church patronage, theatre, education).culture is made continuously and Shakespeare's text is reconstructed, reappraised, reassigned all the time through diverse institutions in specific contexts. What the plays signify, how they signify, depends on the cultural field in which they are situated" (Dollimore and Sinfield, 1985, p. V111). There are some other interesting approaches to Hamlet's character. Hooper highlights the puns and the dangerous doubles as he finds them in the characters of Hamlet and Claudius in his research paper entitled "Dangerous Doubles: Puns and Language in Shakespeare's Hamlet Chrestomathy" (2003). Vanessa Pupavac in her paper entitled "Hamlet's Crisis of Meaning, Mental Wellbeing and Meaninglessness in the War on Terror" studied Hamlet in a new perspective of war on terror. Most recently, N. Maleki in his research paper "The Paradigm Examples of Polar Concept in Shakespeare's Hamlet" (2012) has tried to focus on the polar concept for a much deeper understanding and a far joyful enjoyment of Hamlet's world through hierarchizing the different opposing concepts. Charlotte Keys in the chapter four "A Kind of Fighting: Subjective Life in Hamlet" of her Ph.D. Thesis entitled "Shakespeare's Existentialism" submitted to Royal Holloway, University of London proves Hamlet as an existentialist hero.

Moreover, many Marxist literary critics, including Karl Marx and Fredrick Engels studied Hamlet in new and innovative Marxist perspective. Anatoly Lunacharsky, A. A. Smirnov, Mikhail Lifshitz, Christopher Caudwell, L.C Knight, Georg Lukacs, Bertolt Brecht, Raymond Williams and many others describe Hamlet's character in early classical Marxist perspective. The best example of which is Georg Lukacs' theory of realism. He remarks on the plays of William Shakespeare as follows:

"The example of Shakespeare's great tragedies is particularly instructive, because in them the specifically dramatic character of historical charges, of dramatic historicism, is clearly manifest. As a true dramatist, Shakespeare does not try to point a detailed picture of historical and social circumstances. He characterizes the period through his actors. That is, all the qualities of a character, from the ruling passion down to the smallest 'intimate,' yet dramatic, subtlety, are coloured by the age. Nor necessarily in a broad or epic historical sense, but certainly in the historical conditioning of the collision; its essence must derive from the specific determinants of the epoch" (Lukacs, Georg, 1981, p. 137).

Most recently, Catherine Belsey studied William Shakespeare in her book "Critical Practice" (1980) in an innovative Marxist perspective. In this respect, Terry Eagleton's Deconstructive Marxist study of Hamlet is also very interesting and thought provoking. Terry Eagleton writes that the character of Hamlet is "decentred, who does not wish to be part of the Lacanian "symbolic order", and moves toward the realm of "bourgeois individuality" (Eagleton, Terry, 1986, p. 74). Terry Eagleton further writes that Hamlet is "opacity" that means the "enigmatic being legendary in world literature" (Eagleton, Terry, 1986, pp. 7075). Moreover, Fredric Jameson also analyses Hamlet's character in his thought-provoking paper entitled "Marx' Purloined Letter" (1995), reviewing Jacques Derrida's book "Spectres of Marx" in innovative and brilliant Marxist perspective. Richard Halpern's intelligent critical response to "Derrida's Reading of Hamlet and Marx" (2001) in a Marxist perspective, is also an illuminating essay in Jean Howard and Scott Cutler Shershow's edited collection entitled "Marxist Shakespeare" (2001).

These books and research papers are very interesting, most informative and thought provoking on the character of Hamlet in many respects, but no one has yet attempted to compare Hamlet with superfluous heroes of world literature. However, as this literature survey proves that Hamlet and superfluous heroes of world literature fail to find their purpose in their lives, therefore, they may be compared on these grounds. For this reason, the comparison of Hamlet with the other superfluous heroes of world literature is conducted in this research paper in terms of Marxist hermeneutics and in the light of the brilliant ideas of the 
above-mentioned Marxist literary critics.

\section{Hamlet and the Other Superfluous Heroes of World Literature}

In fact, Hamlet is a superfluous hero resembling to great extent with the superfluous heroes of the nineteenth century Russian and European literature. In fact, the superfluous hero is a product of a peculiar socio-economic phenomenon of the nineteenth-century Russia. The superfluous hero represents a particular cultural conflict in a particular space and time that sets him apart from other more or less socially awkward or dissatisfied members of the literary canon. The superfluous hero is the dual product of Russian culture and Western education, a man of exceptional intelligence. Therefore, the superfluous hero is increasingly and painfully aware of his failure to synthesize knowledge and experience into lasting values, whose false dignity is continually undermined by contact with Russian reality, and whose growing alienation from self and others leads to an unabashed exhibition of an indulgence in cowardly, ludicrous, and sometimes destructive instincts. In this sense, the development of the superfluous hero is also characterised by the Russia's troubled relationship with the West-or, initially, its lack of a relationship.

Therefore, the concept of the superfluous hero is halfByronic and half-Hamlet, which is a product of an age of transition from feudalism to capitalism. In this way, the portrayal of the superfluous hero in the novels of the nineteenth century is bound up with dying old order of feudalism and coming new one of capitalism, coming in conflict with the socio-economic conditions of declining the old order of feudalism and the new establishing system of capitalism. This situation of confusion and irresolution is prevailed in the social formation. Therefore, this confusion and indecision of the individual is fully reflected in literature of this age. For example, Leo Tolstoy's Anna Karenina still identified herself with social conventions and her love defied and suffered under the ostracism of social circle she believed she belong to. Moreover, we also find the examples of tragic decision in Edith Wharton's "House of Mirth" and in George Eliot's "Daniel Deronda", consumed by conflicting value systems of personal love and high society recognition and material affluence.

In addition, this superfluous character type provides us with the occasion for comparing him with the same kind of previous types, which the Russian and other writers have depicted in their works of art. In most of the Russian stories and novels, the heroes suffer from their failure to find any purpose in life and their inability to find a decent occupation for themselves. Consequently, they find all occupations, duties and responsibilities tedious and repugnant. In this manner, they reveal the most striking and astonishing resemblance to the flawed figure of Hamlet. We find such superfluous heroes as Alexander Pushkin's Evgenii Onegin, Mikhail Lermontov's Penchorin, Nikolay Gogol's
Tentetnikov, Alexander Herzen's Beltov, Ivan Turgenev's Rudin and the heroes in "Unwanted," and "Hamlet from Shchigry Country", Fyodor Dostoevsky's Stepan Trofimovich Verkhovensky in "The Devils", and Leo Tolstoy's Andrei Bolkonsky in "War and Peace", are almost identical with Hamlet.

In his short story, "Hamlet of the Shchigrovsky District" (1849), Ivan Turgenev recognized Hamlet as the superfluous hero, in which the anonymous narrator narrates his story of attending a dinner party at the home of a landed and serfowning feudal lord. He meets there with a series of would-be Hamlet figures, finding immediately himself amongst the company "a young man of about twenty, blond and myopic, dressed from head to foot in black' and, although he appears shy and withdrawn, he continues to "smile venomously" (Turgenev, Ivan, 1990, p.276). The anonymous narrator then meets Lupikhin, an embittered man who hides a greater personal pain under his stinging witticisms. Retiring to his shared accommodation, the narrator is finally introduced to another clone of Hamlet with whom he happens to fall into conversation during a sleepless night. Recognising him as a metafictional cliché, the character complains bitterly about being "born an imitation of someone else" (Turgenev, Ivan, 1990, p.286). This eccentric caricature of William Shakespeare's Danish prince boasts of his own worthlessness, exaggerates his personal humiliations and repeatedly grumbles about being 'unoriginal'. He eventually says to the narrator, "call me Hamlet of the Shchigrovsky District. There are many such Hamlets in every district; but perhaps, you haven't come across any others" (Turgenev, Ivan, 1990, p.300). Ivan Turgenev's sketch, in its productive, satirical take on Russian "Hamletism", taps into and plays on William Shakespeare's Hamlet's obsession with the notions of imitation, and originality.

In fact, Hamlet like the other superfluous heroes of world literature is also a product of the age of transition, which is known in the history, the era of the Renaissance that follows the decline of the landed and serf-owning nobility and emergence of rising bourgeoisie in England. "The sixteenth century was the era of the Renaissance in England. This fruition of art and philosophy in England was analogous to that of other Western European countries. It also resulted from the radical upheaval in all domains of economic and social life-the decline of the old feudal order with its method of production, which was now being replaced by capitalist relations characteristic of the epoch of primary accumulation" (Smirnov, A.A.1936, p. 5). This situation formed the so-called gentry, composed principally of the middle and petty landed and serf-owning nobility, which, by fusing with the old landed and serf-owning nobility, replenished its ranks, which marked the beginning of that squirarchy which ruled England from the time of Queen Elizabeth to the middle of the nineteenth century. The new class of wealthy peasant farmers, the so-called yeomanry that was the backbone of old England, degenerated during the sixteenth century. This new landowners drawn from the bourgeoisie and the nobility dislodged it. Therefore, it was 
forced to accept the status of tenants.

On the other hand, the new joint-stock companies (including the paying troupes) were proto-capitalist and operated outside the regulatory systems of the guild structure. They depended on monopolies granted by the monarch in Britain. Catherine Belsey inadvertently gets closer to the nub of the matter when she observes, ".the selling monopoly was one of the means by which the Tudors and Stuarts sought to evade parliamentary control," so that rather than a simple struggle between the old feudal ways embodied in a modified monarchy and the demands of the rising urban bourgeoisie. (Belsey, Catherine, 1985, p. 93)

In this period of transition, the process of rejection of old social values and adoption of the new ones was a continuous process in every sphere of the Elizabethan social formation of England. The situation was truly dialectical: the aristocracy, not the bourgeoisie or bourgoisified nobility produced the conditions for primary wealth accumulation that made Britain the first capitalist economy. However, the portrayal of Hamlet is bound up with dying the old order of feudalism and emerging the new order of capitalism, which is yet seeking to be born. In this way, Hamlet is repetitive of this transitional epoch of England. Terry Eagleton writes, "Hamlet is a radically transitional figure, striking out between a traditional social order to which he is marginal, and a future epoch of achieved bourgeois individualism, which will surpass it. But because of this we can glimpse in him a negative critique of the forms of subjectivity typical of both of these regimes" (Eagleton, Terry, 1986, p.74). Therefore, Hamlet comes in conflict with the socio-economic conditions of declining feudalism; when this situation arises, inner changes occur in Hamlet's personality.

In this manner, Hamlet is as indecisive as the superfluous heroes of Mikhail Lermontov's "A Hero of Our Time," and Turgenev's stories, who would be Romantic heroic figures, unable to find purpose in their lives. However, it is noteworthy that these superfluous heroes sometimes are not doomed to failure in their actions because of their heroic and romantic deeds. The superfluous heroes found purpose through their action, including adventurous or violent action: the hero's soldiering or duelling for example, the death of Alexander Turgenev's Rudin on the Paris barricades in 1848 or self-sacrifice in the form of guillotining of Charles Dickens' hero Sidney Carton in "The Tale of Two Cities."

However, Hamlet also shares the gallivanting heroic deeds with these superfluous heroes of world literature. In fact, Hamlet was the new kind of Elizabethan ideal of a gentlemen, a good all-rounder, scholar, courtier and soldier, like Sir Philip Sidney, something of romantic chivalrous hero. For this reason, Hamlet as a young melancholy university student is not the ideal of the crowd of people. Even King Claudius, his one of the most deadly enemies, admits that Hamlet is popular with the "distracted multitude." Since Laertes went to France, Hamlet has been "in continual practice" with the foils, and if he was fond of fencing he probably tried his hand at other sports. In the sea fight, he led the attack against the sea pirates, taking the lead "in the grapple alone boards the pirate ship" (Shakespeare, William, 2005, Act1V, Scene V1, 14-18). Moreover, he was obviously fond of the stage. Further had Hamlet been the recluse that the king and queen would have noticed no great change in him. The very fact that they noticed his distemper described that he must have been something different before these events. Everything goes to show that he is naturally an active young university student, fond of his studies, sports, games and good mixer. In this way, he possesses striking resemblance to the above-mentioned superfluous heroes of world literature.

Like other superfluous heroes of world literature, Hamlet is rebellious against tradition and existing social order; he suffers the same downfall as that of the other superfluous heroes of world literature. Nevertheless, Hamlet fails to find his purpose in his life and love because of his superfluous indecision and procrastination, however, the ghost of Hamlet's dead father as a state apparatus constructs him as a subject to realise him that he is sole and real heir of the throne of Denmark. He assigned him the role to instruct him to take his revenge from the King Claudius and regain the throne of Denmark. The other Ideological state apparatuses also make Hamlet believe that he is source of all values, sole and real heir of the state of Denmark and assigned him the role to take revenge of his father from his uncle King Claudius and regain the kingship of Denmark. In this manner, Hamlet becomes shaped and circumscribed as a subject by the Ideology and ideological state apparatuses, the social structures, values, and assumptions.

Like other superfluous heroes of world literature Hamlet possesses a feudal background. His upbringings in the royal court and his higher university education make him believe that he is the most extraordinary person, source of all values and prince in Denmark. Therefore, he privileges and protects his unique sense of self and regards this feeling as an extraordinary figure in Denmark. However, when Hamlet is visited by his father's ghost, who informs him that he was murdered by Claudius, therefore, the duty of revenge falls upon the shoulders of Hamlet but he feels himself ill-situated for it. He feels his inadequacy and inability for the task imposed upon him. He thinks, "The time is out of joint: $\mathrm{O}$ cursed spite. That ever I was born to set it right!" (Shakespeare, William, 2005, Act 1, Scene V, 188-189).

In this sense, Hamlet shoulders the burden of his duties and responsibilities as a prince of the state of Denmark. His first impulse is to "sweep to his revenge" "with wings as swift as meditation or thoughts of love". By adhering to his father's dictum and 'setting things right', Hamlet will not be acting on his own terms in his own way, and therefore, will be a hypocritical as those around him. Instead, Hamlet cannot find a proper way to act and exist. His short-lived enthusiasm reduces to prudentially relaxing in indolence and procrastination. For this reason, Hamlet finds very difficult to avenge his father's murder. Yet he still feels an obligation to fulfil these expectations. Something of this idea emerges when Hamlet gives advice to his mother, telling her: "Assume a virtue if you have it not. That monster Custom, 
who all sense doth eat of habits devil, is angel yet in this, that to the use of actions fair and good. He likewise gives a frock or livery. That aptly is put on" (Shakespeare, William, 2005, Act III, Scene 1V, 158-63).

In fact, Hamlet gets a crushing blow when his ideal of womanhood, his mother Queen Gertrude is wedded with King Claudius, his uncle less than two months after his father's death. Therefore, he has a poor opinion of woman, thinking that, "Frailty thy name is woman!-" (Shakespeare, William, 2005, Act 1, Scene 11, 148). Therefore, Hamlet's childish attachment to his mother and his over-emotionalism in his action suggest that he is indecisive and irresolute. Rejecting Gertrude's question "Why seems it (grief at death) so particular with thee?" (Shakespeare, William, 2005, Act 1, Scene 11, 75), Hamlet insists:

"Seems, madam? Nay, it is. I know not 'seems'.

'Ts not alone my inky cloak, good-mother,

Nor customary suits of solemn black,

Nor windy suspiration of forced breath,

No, nor the fruitful river in the eye,

Nor the dejected haviour of the visage,

Together with all forms, moods, shows of grief

That can denote me truly. These indeed 'seem',

For they are actions that a man might play;

But I have that within which passeth show,

These but the trappings and the suits of woe" (Shakespeare, William, 2005, Act 1, Scene 11, 76-85).

Moreover, Hamlet's response towards his mother's over hasty marriage with King Claudius is made known as early as the second scene. Hamlet speaks, "A little more than kin and less than kind" (Shakespeare, William, 2005, Act 1, Scene 11, 66). This indicates that Hamlet already suspects something afoul is afoot. Later in the same scene, during his first soliloquy, he describes his disgust with his mother's over hasty marriage, but tells himself he must keep quiet: "But break, my heart, for I must hold my tongue". His thoughts show that Hamlet is not a natural fighter but he is bookish, dreamer and brooding thinker. He cannot understand why he does not act. As he says,

"I do not know

Why yet I live to say 'This thing's to do':

Sith I have cause, will, strength, and means

To do't" (Shakespeare, William, 2005, Act 1V, Scene. 1V, 42-45).

Furthermore, Hamlet also gets questioning the motives of all who are exposed to him. He receives other shocks, which make him want to be out of this loathsome world. He regards Rosencrantz and Guildenstern as his good friends, as his greeting to them shows no less, "My excellent good friends" (Shakespeare, William, 2005, Act 11, Scene 11, 136). When he finds them insincere, he puts them to the test. "Be even and direct with me, whether you were sent for or no?" (Shakespeare, William, 2005, Act 1, Scene 11, 295).They confess that they "were sent for" (Shakespeare, William, 2005, Act 1I, Scene 11, 299). However, Hamlet gets another attack of melancholia, saying that, "Now I am alone" (Shakespeare, William, 2005, Act11, Scene 11, 533) and "....They are not near my conscience" (Shakespeare, William, 2005, Act V, Scene 11, 58).Therefore, Hamlet does distance himself from those who have "the tune of the time' (Shakespeare, William, 2005, Act. V, Scene, 11.169-70). On hearing the distant wedding revelries, Horatio asks, "Is it a custom?" (Shakespeare, William, 2005, Act I, Scene 1V, 12), to which Hamlet replies:

"Ay, marry is't,

But to my mind, though I am native here

And to the manner born, it is a custom

More honoured in the breach than the observance" (Shakespeare, William, 2005, Act I, Scene 1V, 13-6).

Latter like other superfluous heroes Hamlet also becomes disillusioned and disenchanted man, when gloom has settled upon him. Therefore, Hamlet turns largely sceptical about what he sees as degrading customs and general opinions of the given social formation. "And indeed Hamlet dreams of a world which has been somehow made straight, a world of honest people, honest relationships, but he does not believe that such world will ever in fact become reality" (Lunacharsky, Anatoly, p. 237). Thus, Hamlet cries out against his fate that requires him to act: When Hamlet finds his own death warrant in the purloined letter, (Shakespeare, William, 2005, Act V, Scene 11, 6-7), he seems to be confirmed in that view, leaving it to chance because he realizes the power of destiny: ".and that should learn us. There's a divinity that shapes our ends, Roughhew them how we will" (Shakespeare, William, 2005, Act $\mathrm{V}$, Scene 11, 10-11) and that "We defy augury. There is special providence in the fall of sparrow" (Shakespeare, William, 2005, Act V, Scene 11, 197-198).

At last, Hamlet fails to take revenge and regain the kingship of Denmark because of his indecision and procrastination. This is even more impressive when taken in light of Terry Eagleton's point in his short book "William Shakespeare" that "Hamlet has no 'essence' of being whatsoever, no inner sanctum to be safeguarded: he is pure deferral and diffusion, a hollow void which offers nothing determinate to be known" (Eagleton, Terry, 1986, p. 72). Actually, Hamlet's all utterances show ideology of time because ideology is present in every word he utters in his speeches. As Catherine Belsey remarks that ideology is engraved in each and every utterance and use of language but there are some other signifying systems of the social formation also where its presence can be traced easily: common sense, everyday behaviours mores and folkways, myths, social gestures and routine truisms are relevant signs in this regard (Belsey, Catherine, 1980, pp.56-85).

However, Hamlet becomes entrapped in indecision and procrastination. He bears the latent passion of a hesitating breeze. He breathes with hesitation, irresolution and delay. Laurence Olivier posits that Hamlet is "the tragedy of a man who could not make up his mind" (quoted in Alexander, Peter, 1953, pp. V-V1). Hamlet's purpose exists in a perpetual state of twilight of confusion, indolence and indecision. Repeatedly, his compulsive tendency to analyse and question distracts him away from revenge in every 
situation he faces. In this manner, Hamlet loses his will to act, even to live and "unpack his heart with words" (Shakespeare, William, 2005, Act. 11, Scene 11, 572). He thinks, "How all occasions do inform against me..." (Shakespeare, William, 2005, Act. 1V, Scene 1V, 32). Moreover, he is tragically doomed to failure in revenging his father. In this manner, he possess two wills the will to revenge and the will of indolence and procrastination. Consequently, his inner conflict causes insomnia: "sir, in my heart there was a kind of fighting. That would not let me sleep" (Shakespeare, William, 2005, Act. V, Scene 11, 4-5). As a result, he turns epitomized in conflict of the two wills as Christopher Caudwell remarks:

"In Hamlet the problem of conflict of unmeasured wills is posed in yet another form - here a man's will is divided against itself, and therefore even though nothing 'external' can oppose or reflect it, it can yet struggle with itself and be wrecked. This 'doubleness' of a single will is aptly symbolized by the poisoned swords and goblet in which one aim is as it were two-faced, and secures opposite ends" (Caudwell, Christopher, 1977, pp. 87-88).

Nevertheless, Hamlet's postponement of the killing of Claudius is his reluctance to murder the King Claudius while he is praying that his soul should enter heaven. However, it is not so much his hesitation, as the tone that Hamlet adopts when he speaks of his revenge that proves him lacking in will-power. He is horrified by the crime, by his mother's inconstancy in marrying the usurper, "ere those shoes were old," and by the rampant hypocrisy and debauchery of the entire court, even of his beloved Ophelia, a debauchery and hypocrisy, which he attributes to the world at large. Moreover, Hamlet fails to take revenge of his father from his uncle King Claudius. Finally, he wants to commit suicide but cannot do so because of his indecision, indolence and confusion. Hamlet contemplates the meaning of suicide because of his father's unexpected death and his mother's indecent hasty marriage, which have led him to think about "self-slaughter" (Shakespeare, William, 2005, Act I, Scene 11,132). Then he teasingly speaks of walking out of the air and "into (his) grave" (Shakespeare, William, 2005, Act II, Scene 11,204) with Polonius. He is astonished by the men in Fortinbras' army, who can "Go to their graves like beds" (Shakespeare, William, 2005, Act IV, Scene 1V, 61) for a plot of land that would not be big enough to bury them all in. In his soliloquy, beginning, 'To be or not to be' shows an inbetween state of his mind or inbetweenness of to be or not to be in which he meditates on the desirability and the fear of death. Hamlet suggests that reflection is the adversary of suicide: "To be, or not to be - that is the question" (Shakespeare, William, 2005, Act III, Scene 1, 55). The world and life he sees is painfully purposeless and pointless, and this is what entices him to contemplate suicide but he cannot do so because of his superfluous class nature and indolence. Finally, he is doomed to fail in his life.

\section{Lost Love of Hamlet and Other Superfluous Heroes of World Literature}

The astonishing similarity Hamlet has in common with the superfluous heroes of world literature is that Hamlet and the superfluous heroes not only fail to find purpose in their lives but also are unable to find meaning in their love. For example, Alexander Pushkin's superfluous hero Onegin leads a feudal life in which there is no hardship but only comfort:

"Sound sleep, a stroll, an entertaining book,

A forest glade and a babbling brook,

A dark-eyed beauty,

Young and fresh to kiss sometimes,

The bridle of restive steed,

Dinner to suit his fastidious needs,

A bottle of light wine,

Solitude, tranquility,

Holy is the life of Onegin leads...."

Onegin is romantic as well as superfluous hero, who can really capture the heart of woman but he does not contemplate which dimension to follow for achieving his destination. He is sated with all pleasures that money can buy in his youth. Later, he gets bored with everything because that has brought no solace to his heart. He gives up everything and every social relation with the other people around him:

"Weary of inconstancy

And friends and friendship too".

As a result, he lost his love and his beloved Tatyana reject Onegin at the end of the novel:

"I love you (why conceal it?),

But to another my troth is plighted,

To him forever I'll be true".

Similarly, here is the other superfluous hero of Mikhail's Lermontov's novel "A Hero of Our Time" Pechorin who hampers his ability to find satisfaction, meaning and purpose in his life. Like Don Juan, he loves all women but loves no woman. He himself describes as follows:

"As a young man, as soon as I got my freedom I threw myself wildly into all the pleasures that money can buy, and soon grew sick of them. Then I went in for society high-life and before long, I was tired of that too. I fell in love with women of fashion and was loved in return. But their love merely stirred my imagination and vanity, my heart remained empty. I took to reading and studying, but grew tired of that too. I saw I had no need of learning to win fame or happiness, for the happiest people are the ignoramuses" (Lermontov, Mikhail, 1966, p. 35).

At last, Pechorin grows bored with his pursuit of pleasures when he attains them. Subsequently, he is unable to settle down and enjoy life, finding social life superfluous. Therefore, he spends his all youth to chase rare butterflies and when he captures his first rare butterfly, he does not like it and ceases to pursue rare butterflies. In this way, he captures love but he soon realises that he does not want it. As 
he claims, "there's boundless pleasure....in taking possession of a young, fresh-blossomed heart" (Lermontov, Mikhail, 1966, p. 103). In this way, his relationship failed with Princess Marry and Bela. At last, Princess Marry begins to abhor Pechorin, when she realises that he does not love her. After that Pechorin marries Bela and admits that he is "still in love with her", that he would "give his life for her...But she bores him" (Lermontov, Mikhail, 1966, p. 35). The case of Ivan Turgenev's superfluous hero Rudin is also the same. He begins everything passionately but finishes nothing in his life. He falls in love with a beautiful girl named Natalya who tells him that she is willing to get married with him although her mother has forbidden her to do so. Rudin answers her: "Good God! Your Mama disapproves! What an expected blow! God, how soon. There is nothing to be done, we must be resigned...." However, Natalya leaves Rudin only because he himself obdurate from the very beginning and on seeing him off she realizes that he does not love her. In this way, Rudin lost his love.

Here is another superfluous hero Oblomov of Ivan Goncharov's novel "Oblomov". Oblomov is principally a kind of lethargic and indecisive person, who shortly rouses from his dressing-gown torpor by the attraction of pretty, untamed and energetic girl named Olga Sergievna Ilyinitch. In this way, she totally changed him. Slowly, he abandoned his lethargic habits and began to live a normal one. As we find in the novel, "Whenever she detected in his soul-and she could probe that soul very deeply-the least trace of its former characteristics, she would work for him to heap himself with reproaches for his lethargy and fear of life" (Goncharov, Ivan, 1915, p. 177). Lastly, Oblomov grows tired, bored and weary of the love affair of pure and simple-hearted Olga, of whom he is fond and becomes dissatisfied, disenchanted and disillusioned for his superfluous impulses. Moreover, on the contrary, Olga tries very hard to persuade him to ask her hand from her aunt but all in vain. In this manner, Oblomov delays and defers his marriage because of his indolence, procrastination and indecision. Consequently, he can neither take decision to complete his agricultural schemes nor marry Olga. Subsequently, he spends an enchanted summer in gentle courtship of Olga (Goncharov, Ivan, 1915, part 11 and 111 of the novel, pp. 157-232), only to retreat again into his dressing-gown existence when the cold winter season approaches. (Goncharov, Ivan, 1915, pp. 265, 248-249). At last, Olga rejects him as Tatyana reject Onegin at the end of the romance. Therefore, she leaves Oblomov, striving towards something and at last, finds it in Schtoltz, which Oblomov lacks. Therefore, she joins and marries Schtoltz.

It is obviously clear that all these features of the abovecited superfluous heroes are almost identical with Hamlet's character. He is not behind his brothers superfluous heroes of world literature in this respect. In this way, Hamlet's superfluous attitude to love is similar to that of the other superfluous heroes of world literature. The most interesting aspect of Hamlet's superfluous attitude is his relationship with Ophelia. However, Hamlet has expressed many "tenders of his affection" "in honourable fashion," and with "holy vows of heaven." He falls in love with Ophelia, writes poetry for, and letters to her. Ophelia reveals the character of love in three short speeches to her father; he demands to know the truth. She is promising to obey her father that, "My dear father, I did nothing more than obey your orders by rejecting his communications and refusing to allow him to see me" (Shakespeare, William, 2005, Act 11, Scene 11, 26-27). In this way, she renounces her love for him, surrenders the love letters and poems he has written for her. After this, Hamlet's love turns to misogynistic contempt. The disastrous end of initial hope has occurred about through an encounter in which Hamlet has stormed at her to get her to a nunnery. This is the moment of crisis in Hamlet's relations with Ophelia. Hamlet is more indignant at her double-dealing. It undoubtedly grieves Hamlet to break with Ophelia. He cannot trust Ophelia and denies his own love for her:

"Hamlet. I did love once.

Ophelia: Indeed, my lord, you made me believe so.

Hamlet: You should not have believed me, for virtue cannot so inoculate our old stock but we shall relish of it. I love you not.

Ophelia: I was the more deceived.

Hamlet: Get thee to a nunnery. Or if thou wilt need marry, marry a fool, for wise men know well enough what monsters you make of them. To a nunnery go-and quickly too. Farewell" (Shakespeare, William, 2005, Act 111, Scene I, 115-142). Perhaps Ophelia's reply to Hamlet after he makes a series of lewd jibes at her expense during the performance of The Mousetrap, "You are naught, you are naught" (Shakespeare, William, 2005, Act III, Scene 11, 140), amounts for that Hamlet is being 'improper' or 'offensive'. When Laertes sees Ophelia who, in a state of madness, has become "Divided from herself and her fair judgement" (Shakespeare, William, 2005, IV, Scene V, 85), he remarks,

"Nature is fine in love, and where 'tis fine

It sends some precious instance of itself

After the thing it loves" (Shakespeare, William, 2005, Act IV, Scene, 1, 257).

At last, Ophelia drowns hanging garlands on a willow. The flowers that should have decked her bride-bed are strewed upon her grave. The Queen's most explicit statement: "I hoped that thou shouldst have been Hamlet's wife" (Shakespeare, William, 2005, Act V, Scene 1, 227) hints Hamlet's love for Ophelia. In fact, Hamlet wishes to marry Ophelia. Hamlet later admits on Ophelia' grave that, "I loved Ophelia. Forty thousand brothers could not with all their quantity of love Make up my sum." (Shakespeare, William, 2005, Act IV, Scene, VI 279-281). In this way, Hamlet lost his love forever.

\section{Conclusion}

This research paper tries to prove Hamlet as a superfluous hero because he resembles to great extent with the superfluous heroes of world literature. Actually, his Hamletism is because of his inability to find purpose, meaning and dimension in his life and love and his failure to 
have successful relationships with others especially with Ophelia. Therefore, this research paper highlights Hamlet's striking and astonishing resemblance with the superfluous heroes of world literature. At the end of this analytical and comparative study of them, the noticeable point is that in fact, the superfluous heroes including Hamlet are product of the transitional historical era from feudalism to capitalism, when the old social values and traditions are rapidly waning and the new ones are not coming into existence.

However, the employment of Marxist hermeneutics in this comparative study yielded the result that the superfluous heroes belong to the decadent land-owning and serf-owning aristocrat class, representing class confusion, irresolution and procrastination of the intelligentsia of their age. It can easily be inferred from this comparison that the superfluous disappointment and disenchantment of the superfluous heroes of world literature with the existing social formation and status quo of their era and their inability to find dimension and desire to change them may be termed as Hamletism or Oblomovism. In fact, Hamletism or Oblomovism is based upon the private property, which breeds and nourishes this type of negative and flawed characters that will completely disappear with the elimination of the social formations based upon private property in future social formation of Communism.

\section{References}

[1] Alexander, Peter. (1953). Hamlet Father and Son: The Lord Northcliffe Lectures University College. London, Oxford: Clarendon.

[2] Belsey, Catherine. (1980). Critical Practice. London: Great Britain: Routledge.

[3] Belsey, Catherine. (1985). the Subject of Tragedy: Identity and Difference in Renaissance Drama, London: Methuen.

[4] Caudwell, Christopher. (1977). Illusion and Reality. London: Lawrence \& Wishart.

[5] De Grazia, Margreta. (1999). "Teleology, Delay, and the Old Mole”. Shakespeare Quarterly 50.3: pp. 251-267.

[6] Eagleton, Terry. (1986). William Shakespeare. Oxford: Basil Blackwell.

[7] Hooper, T. (2003). Dangerous Doubles: Puns and Language in Shakespeare's Hamlet Chrestomathy: Annual Review of Undergraduate Research at the College of Charleston Volume 2, pp. 120-134.
[8] Hooti, Noorbakhsh. (2013). William Shakespeare's Hamlet: A Deconstructive Study. International Research Journal of Applied and Basic Sciences 2013 www.irjabs.com ISSN 2251-838x/ Vol, 4 (12): pp.3903-3909. Science Explore Publication.

[9] Jameson, Fredric, (1995). Marx's Purloined Letter. New Left Review. 1/209, January-February 1995.

[10] Jenkins, Harold. (1982). Introduction. Hamlet. Arden ed. London: Methuen.

[11] Jones, Ernest. (1976). Hamlet and Oedipus. New York: Norton.

[12] Jump, John. (ed.) (1968). Shakespeare: Hamlet: A Selection of Critical Essays. London: Macmillan.

[13] Keys, Charlotte. Shakespeare's Existentialism. Royal Holloway, University of London. A Ph.D. Thesis.

[14] Lacan, Jacques (1959). "Desire and the interpretation of desire in Hamlet," in Felman, Shoshana (ed.), Literature and Psychoanalysis, the Question of Reading: Otherwise, Yale French Studies 55/56, New Haven, Yale University Press, pp.11-52.

[15] Lermontov, Mikhail. (1966). A Hero of Our Time. Trans. Paul Foote. New York: Penguin Books.

[16] Lukacs, Georg. (1981). the Historical Novel. London: Penguin Books.

[17] Lunacharsky, Anatoly. (1973). "Bacon and the characters of Shakespeare's Plays" in Lunacharsky on Literature and Art, pp. 218-243.Moscow: Progress Publishers.

[18] Maleki, N. (2012). The Paradigm Examples of Polar Concept in Shakespeare's Hamlet. Global Journal of Human Social Science, Volume 12, Issue 1, pp.19-23.

[19] Niekerk, Marthinus Christoffel Van. (2003). Shakespeare's Play: deconstructive Reading of the Merchant of Venice, the Tempest, Measure for Measure and Hamlet.

[20] Pupavac, Vanessa. (2008). "Hamlet's Crisis of Meaning, Mental Wellbeing and Meaninglessness in the War on Terror" in: Mental Health Review Journal Volume 13 Issue 1, March 2008, pp. 14-26.

[21] Shakespeare, William. (2005). Hamlet, the Prince of Denmark. London: Penguin.

[22] Smirnov, A.A. (1936). Shakespeare: A Marxist Interpretation, New York: Critics Group.

[23] Turgenev, Ivan. (1990). Sketches from a Hunter's Album, trans. Richard Freeborn. London: Penguin. 